characters although perhaps only superficially similar. The median thoracic suture so pronounced in Dinapsis and Prodinapsis occurs elsewhere, so far as I am aware, only in certain Ceraphronidæ, Scelionidæ and Belytidæ of the Serphoid series where it may or may not be associated with the paired parapsidal furrows, although a few Bethylidæ and the Ampulicidæ have a median pronotal (not mesonotal) furrow. In Megalyra it is prominent and undoubtedly homologous to the one in Dinapsis.

\title{
RECENT Books.
}

In these lists are included titles relating entirely or directly to insects, as well as books in the related fields of biology which are of immediate interest to the Entomologist.

Folsom, $J . W$. Entomology, with Special Reference to its Ecological Aspects. pp. 502, extensively illustrated. P. Blakiston's Son \& Co. Philadelphia, 1922. A third edition of this well known and useful text, containing much new material, and needing no introduction to American entomologists.

Parker, G. H. Taste, Smell and Allied Senses in the VerTEBRATES. pp. 192, illustrated. J. B. Lippincott Co., Philadelphia $\$ 2.50$. Relates specifically to the vertebrates from the standpoint of both anatomy and physiology and presents material that the entomologist will find very useful.

Rousseau, $E$. Les LARVes ET NyMphes AQUATIQUes DES INSECTES D'Europe. vol. 1, pp. xx 967, 344 figures. J. Lebeque, Brussels. The first volume includes the Rhynchota neuropteroids and Trichoptera. A very complete and well illustrated compendium on the biology, morphology and classification of the aquatic members of these groups, with extensive bibliographical references. 
Bouvier, E. L. The Physic Life of Insects. English translation by L. O. Howard, pp. XVI†377 New York, The Century Co.

Dr. Howard has made available to the English-reading public, in a most excellent translation, Bouvier's highly entertaining and stimulating treatment of insect-behavior.

Lavier, Geo. Les parasites des invertébrés hématophages; PARASITES QUI LEUR SONT PROPRE; PARASITES QU'ILS transmettent aux vertébrés. 218 pp. illus. Paris, Vigot Frères, 1921.

A very complete account of the microparasites of bloodsucking insects and of their relations to disease in man and other vertebrates.

\section{PROCEEDINGS OF THE CAMBRIDGE ENTOMO- LOGICAL CLUB}

March 14, 1922, Mr. C. W. Johnson showed a collection of New England Hippoboscidæ and gave an account of their habits, classification and distribution. See vol. 39, Nos. 4-6.

Mr. W. J. Clench showed the milkweed beetles Tetraopes tetraophthalmus and canteriator and a supposed hybrid between them.

Prof. W. M. Wheeler told about a mass of saw-fly larvæ, which he had observed in South America, moving slowly through the wet grass like a single animal. Mr. C. W. Johnson called attention to a similar habit in the dipterous genus Sciara in which the larvæ cluster together in a long narrow mass which moves along like a w.orm. See vol. 29, Nos. 4-6.

April 11, 1922. Mr. F. Waldo Dodge showed a collection of over a hundred species of the coleopterous family Tenebrionidæ. He also gave an account of the common species of Coccinella, illustrated by drawings. 

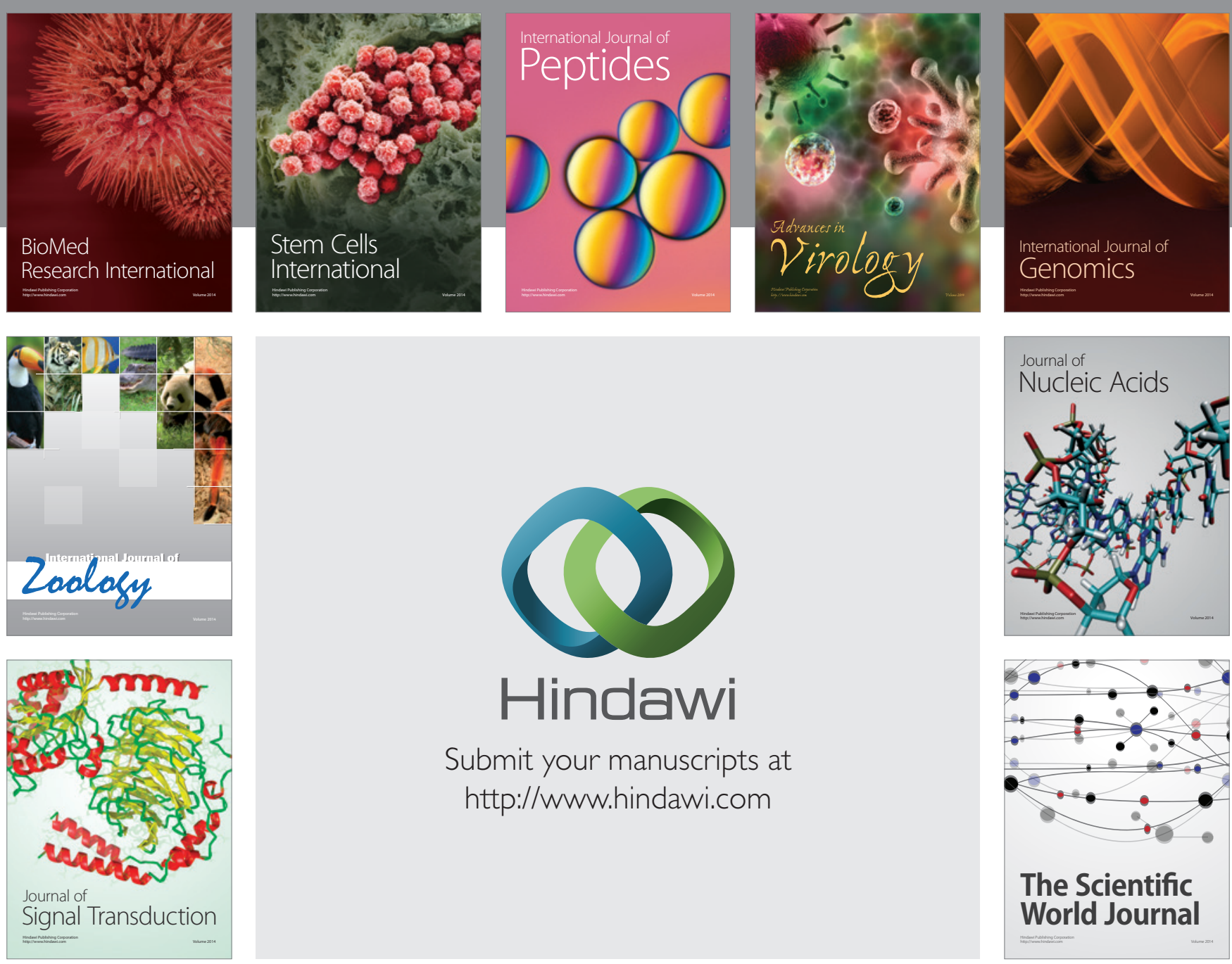

Submit your manuscripts at

http://www.hindawi.com
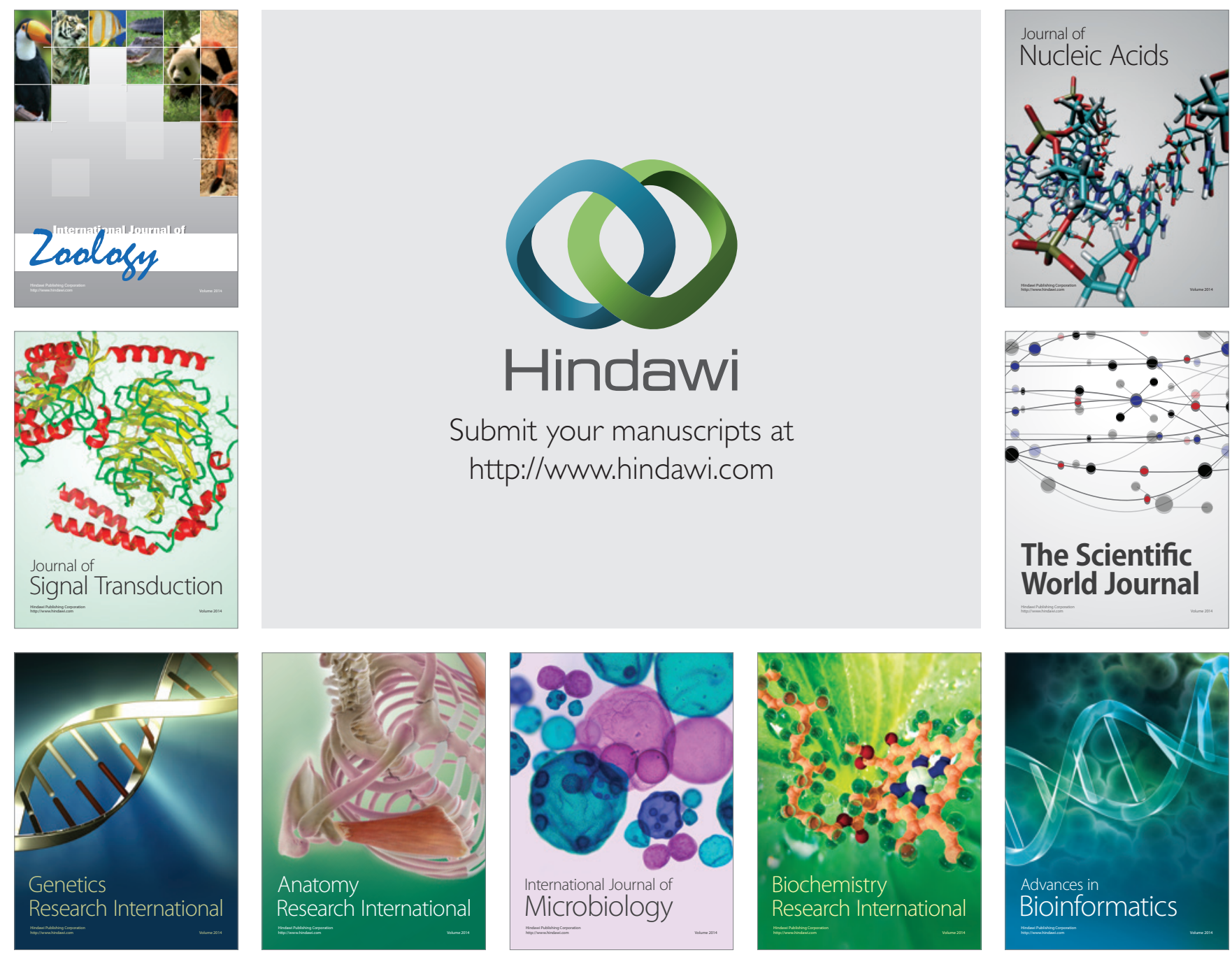

The Scientific World Journal
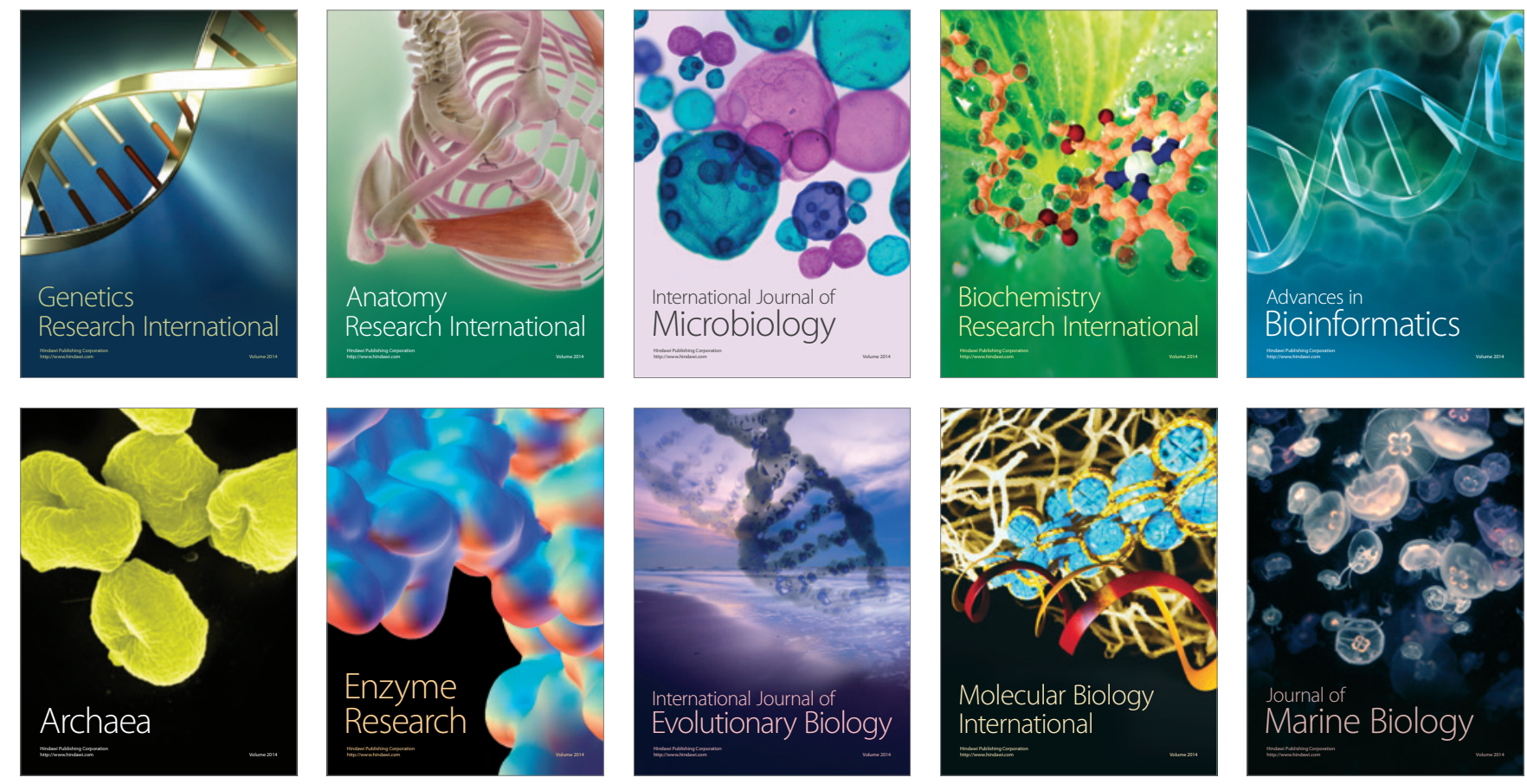